\title{
Anthropology and Cultural Heritage
}

Gilberto Velho

\begin{abstract}
The author argues that anthropology can help define a much broader, richer and culturally more diverse concept of heritage. He advocates for a more democratic and pluralist State policy that takes into account the diversity and complexity of Brazilian society, valuing traditions, symbolic systems and cultural manifestations from all sectors. The preservation of the Terreiro de Candomblé Casa Branca, in Salvador, Bahia, is presented as an example of recognizing the legitimacy of a tradition that was until recently subject to discrimination and persecutions. The author argues that this broadening of the concept of cultural heritage is crucial to the constitution of a Brazilian society that values democracy, human rights, citizenship and its own memory as a nation.
\end{abstract}

Keywords: cultural heritage, anthropology, preservation, policy, diversity.

\section{Resumo}

O autor argumenta que a antropologia pode contribuir para a definição de um conceito de patrimônio mais amplo, rico e diversificado culturalmente. Defende uma política de Estado mais democrática e pluralista, que leve em conta a diversidade e a complexidade da sociedade brasileira, valorizando tradições, sistemas simbólicos e manifestações culturais de todos os segmentos sociais. O tombamento do Terreiro de Candomblé Casa Branca, em Salvador, Bahia, é apresentado como um exemplo do reconhecimento e da legitimidade de uma tradição que já foi objeto de discriminação e perseguições. O autor defende que esta ampliação do conceito de patrimônio cultural é crucial para a constituição de uma sociedade brasileira que valorize a democracia, os direitos humanos, a cidadania e a sua própria memória como nação.

Palavras-chave: patrimônio cultural, antropologia, tombamento, política, diversidade. 


\section{Anthropology and Cultural Heritage}

Gilberto Velho

Time present and time past

Are both perhaps present in time future,

And time future contained in time past.

T.S. ElLiot

The issues surrounding the preservation of Brazil's heritage have led to a growing involvement of anthropologists in discussions and decisions that until very recently were the domain of architects and lawyers. Although the work to protect the country's historical heritage has included a broadly anthropological concern from the outset, today the development of Anthropology on one hand and the amplification of the concerns with cultural heritage on the other means that the more specialized knowledge of the professional anthropologist is needed. This new situation should be seen as positive, so long as we also strive to avoid dogmatisms and any corporativist sectarianism.

As we know, anthropology has many schools and diverse theoretical approaches, meaning there is no single 'anthropological formula' capable of responding to the issue of cultural heritage. I would argue, though, that anthropological thought as a whole involves a relativizing perspective, which allows us to think through a number of questions that, while not new, have become more pressing. A modern, complex and heterogeneous society like Brazil's is characterized by the more or less harmonious coexistence of different traditions and worldviews. ${ }^{2}$ The observation of differences, diversity and sometimes contradictions does not imply being oblivious to the existence of a more encompassing sociocultural system linked to the very idea of nation.

1 Originally published as "Antropologia e patrimônio cultural”. Revista do Patrimônio Histórico e Artístico Nacional, n. 20, 1984, pp.37-39.

2 See Velho and Viveiros de Castro, 1978. 
In this sense, a State cultural policy that aims to be more democratic and pluralist must adequately take into account the question of diversity. This is not an easy or immediately resolvable task. Traditions legitimized by the elites tend to dominate and these are unlikely to face serious polemics or doubts. But the problems become more complex when we turn to the customs and values of groups and sectors occupying subordinate and hierarchically inferior positions in society. The channels of communication themselves are precarious, and the meaning of certain demands and how to make them compatible with official policy often far from clear. It is here that the anthropologist's work and experience can be fundamental. The anthropological tradition has developed largely from a continual experience of dealing with the other, while perceiving the fragmentation that can exist in apparently monolithic units. This permanent interplay of estrangement and relativization ${ }^{3}$ may be a fertile path for capturing the symbolic importance of manifestations that do not automatically fit into the formulas existing today to protect the nation's cultural heritage.

One of the main, albeit not exclusive, focal points of anthropological work has been to investigate groups located on the margins of official history and the dominant culture. Very often their beliefs and values are transmitted through oral traditions. Dates may be imprecise and documentation slight or even non-existent. These are also groups with their own identity, marked by symbolic systems often inaccessible to the traditional elites. The task, therefore, is to interpret the meaning of rituals, sites, etc. within their specific contexts. This was precisely what enabled the recent preservation of the Terreiro de Candomblé Casa Branca, a famous candomblé temple in Salvador, Bahia. ${ }^{4}$ It was without doubt a rich and fascinating situation given the site's huge importance and significance for vast sections of Brazilian society and the fact it found itself under threat. The decision to list the temple implies recognition of the legitimacy of both a cultural tradition and a system of values that until relatively recently were subject to discrimination and sometimes persecutions. As a result of this initiative, Brazilian society is recognized to be much richer and more culturally diverse than the image afforded by a more traditional view of heritage.

3 See DaMatta, 1978 and Velho, 1978.

4 See "Ilê Axé Iyá Nassô Oká - Casa Branca Temple" in the present edition. 
Undoubtedly the key issue remains of whether official preservation orders are always the best way of dealing with cultural facts and phenomena in which past and present remain indissociable. It is essential for us to understand how different social groups perceive and represent what we define as heritage. This requires valuing a particular kind of qualitative research typical of the anthropological tradition, participant observation. Only such an approach enables us to capture the complexity of the singular features of specific groups, local and regional history, less privileged groups and traditions and worldviews more distant from the frameworks that have tended to guide most cultural policy decisions. On the other hand we need to avoid, at all costs, falling into a facile and demagogic populism, lacking criteria and frameworks discussed and elaborated through a systematic and interdisciplinary process of reflection.

It is not a question, therefore, of rejecting or disqualifying those aspects of cultural heritage that have thus far received greater attention from government agencies. But in the spirit of Mário de Andrade and other pioneers, this work needs to be amplified, allowing the Brazilian nation to recognize its own complexity. This is a process of research and debate that necessarily implicates different actors. At a time when the importance of civil society has come to the fore, we need to recognize it in all its diversity and density.

As bearers of specialized knowledge, anthropologists, like architects, lawyers, should not be mere mechanical spokespeople for the groups they study, nor should they relinquish their expertise, the outcome of study and experience, that in the long-term can be used in benefit of the same groups. Their role is to engage in an interpretative enterprise, working to make bridges between the different codes and value systems existing in a complex modern society.

At the same time, there is no hiding the fact that every cultural policy is inserted within a field of power, complete with interests, factions and often conflicts. But in recognizing this fact, we must avoid any sociologizing fatalism that could prevent us from transcending the immediatism of present circumstances. A long-term cultural policy that rises above our everyday disputes can only be achieved through an effective policy of knowledge, implying both research and reflection. Anthropology tells us that learning about cultural systems and beliefs is a laborious process demanding time and effort. When turning to the study of our own society, looking to make decisions 
about our own cultural heritage, this care must be redoubled. Brazilian society, as has been amply proclaimed and attested, is constituted by groups widely differentiated in terms of their origin, trajectory and position in the social hierarchy, as well as significant local and regional differences. Where and how these different traditions and experiences meet is a polemical topic. Discontinuity may or may not signify conflict and shared participation in certain beliefs and values does not necessarily express harmony. The more or less tense coexistence of different perceptions of reality forces us to develop more sophisticated methods to account for the complexity of the cultural facts that envelop and constitute us.

Avoiding dogmatism or any claim to omnipotency and omniscience, anthropologists need to assume responsibility for implementing a policy designed to encompass the specific natures of the different identities of the diverse social groups making up national society. These identities are associated with worldviews whose singularity means that they may differ radically from the universe of values and knowledge inhabited by the elites, including scientists and researchers.

This observation, however, does not mean we are condemning to crystallize differences and valorize a cultural monadism. Remaining on the terrain of religion, for example, recognizing the specific ethos of candomblé, umbanda or Kardecist spiritism does not prevent us from perceiving the cultural continuities between these systems, or with popular Catholicism itself.

The anthropologist, though recognizing and calling attention to the specificities of distinct groups, is not unaware of their coexistence within the nation and the reality of the State and its implementation of policies and decisions.

For anthropologists, culture is a useful notion for conceptualizing heritage insofar as it allows us to account for the complex relations between what remains and what changes. As in the verse of Elliot cited at the beginning, past, present and future are subtly and intensely interconnected. In the realm of the cultural arbitrary, we need to stay attentive to these nuances.

By rekindling the debate on cultural heritage, we must be prepared for potential revisions to the legislation that allow support and protection without lapsing into inertia and paralysis. On the other hand, we need to engage in a reading of the existing legislation that facilitates and expedites our goals rather than inhibiting and confining them. 
Expanding the concept of cultural heritage itself, as well as enriching and flexibilizing the means and instruments at our disposal, form part of a broader long-term project for democratizing Brazilian society. At issue is the notion of citizenship, the question of human rights, and, inevitably, the fundamental question of a nation's memory.

\section{Bibliography}

DAMATTA, Roberto. 1978. "O ofício do etnólogo ou como ter anthropological blues". Cadernos de Antropologia Social do Museu Nacional, 1. Republished in: E. Nunes (org.), A Aventura Sociológica. Rio de Janeiro: Zahar. pp. 23-35. VELHO, Gilberto. 1978. “Observando o familiar”. In: E. Nunes (org.), A Aventura Sociológica. Rio de Janeiro: Zahar. pp.36-46 VELHO, Gilberto and VIVEIROS DE CASTRO, Eduardo. 1978. "O conceito de cultura e o estudo das sociedades complexas". Artefato, Jornal de Cultura do Estado do Rio de Janeiro, 1:4-9.

Translated by David Rodgers.

Accepted for publication on April 2, 2012 